\title{
Liquefaction of lignocellulose in Light cycle oil: A
}

\section{process concept study}

Shushil Kumar ${ }^{a}$, Andrejs Segins ${ }^{a}$, Jean-Paul Lange ${ }^{* a, b}$, Guus Van Rossum ${ }^{a, b}$, Sascha R.A.

Kersten $^{a}$

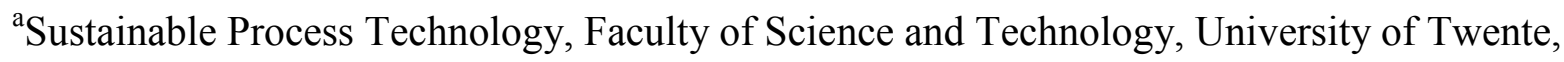

Drienerlolaan 5, 7522 NB, Enschede, The Netherlands

${ }^{\mathrm{b}}$ Shell Global Solutions International B.V., Shell Technology Centre Amsterdam, Grasweg 31, 1031 HW, Amsterdam, The Netherlands

*Corresponding author: jean-paul.lange@shell.com; Tel: +31-20-630 3428

\section{Supporting information}


- Experimental section

Composition of pine wood used in this work is shown in Table S 1 . The missing $8 \%$ of the wood is of extraneous components namely extractive and ash. These components in wood are the substances other than cellulose, hemicelluloses, and lignin. They do not contribute to the cell wall structure, and most are soluble in neutral solvents.

Experimental set-up with a hot filtration and products collection units is shown in Figure S 1. A schematic diagram of the experimental procedure of the refill experiments is provided in Figure $\mathrm{S}$ 2.

Table S 1: Pine wood composition ${ }^{1}$

\begin{tabular}{lclc}
\hline Composition & Value & Composition & Value \\
\hline chemical Analysis & wt. \%, dry & ultimate analysis & wt.\%, daf \\
cellulose & 35 & $\mathrm{C}$ & 46.58 \\
hemicellulose & 29 & $\mathrm{H}$ & 6.34 \\
lignin & 28 & $\mathrm{O}$ (by difference) & 46.98 \\
alkali metals & $\mathrm{mg} / \mathrm{kg}$, dry & $\mathrm{N}$ & 0.04 \\
$\mathrm{~K}$ & 34 & $\mathrm{~S}$ & 0.06 \\
$\mathrm{Mg}$ & 134 & & \\
$\mathrm{Ca}$ & 768 & & \\
total ash & 2600 & & \\
\hline
\end{tabular}




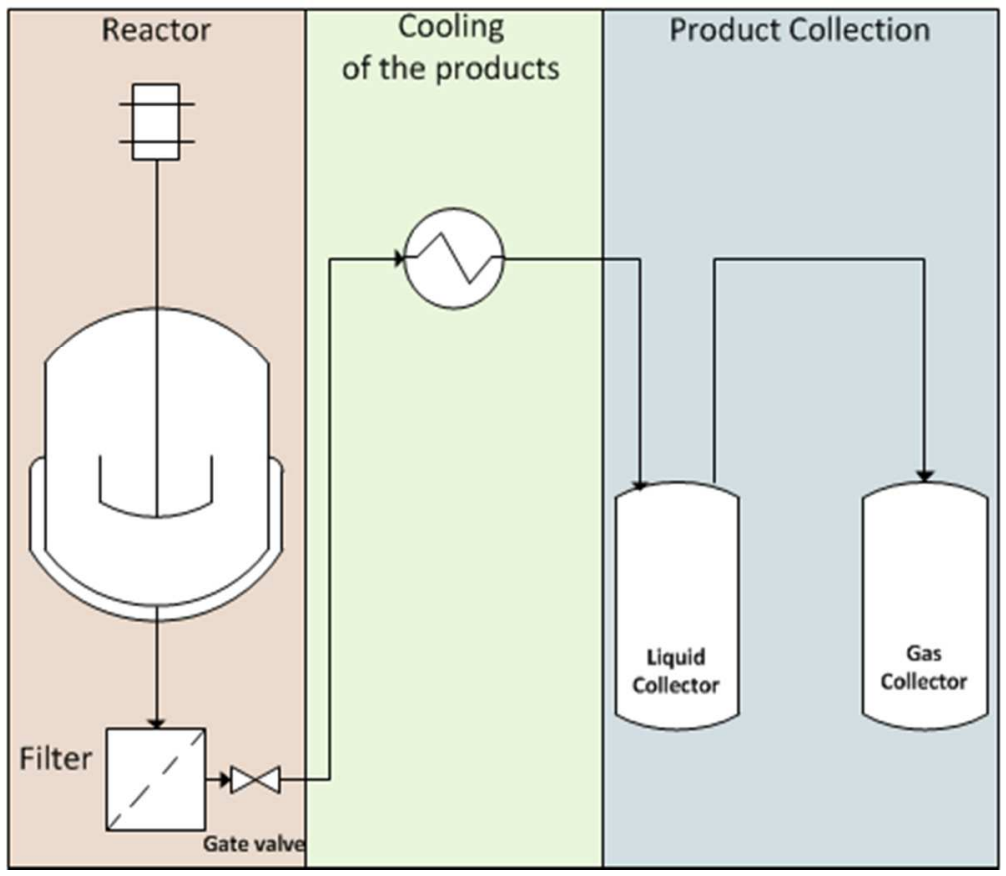

Figure S 1: Experimental set-up with a hot filtration and products collection units. 


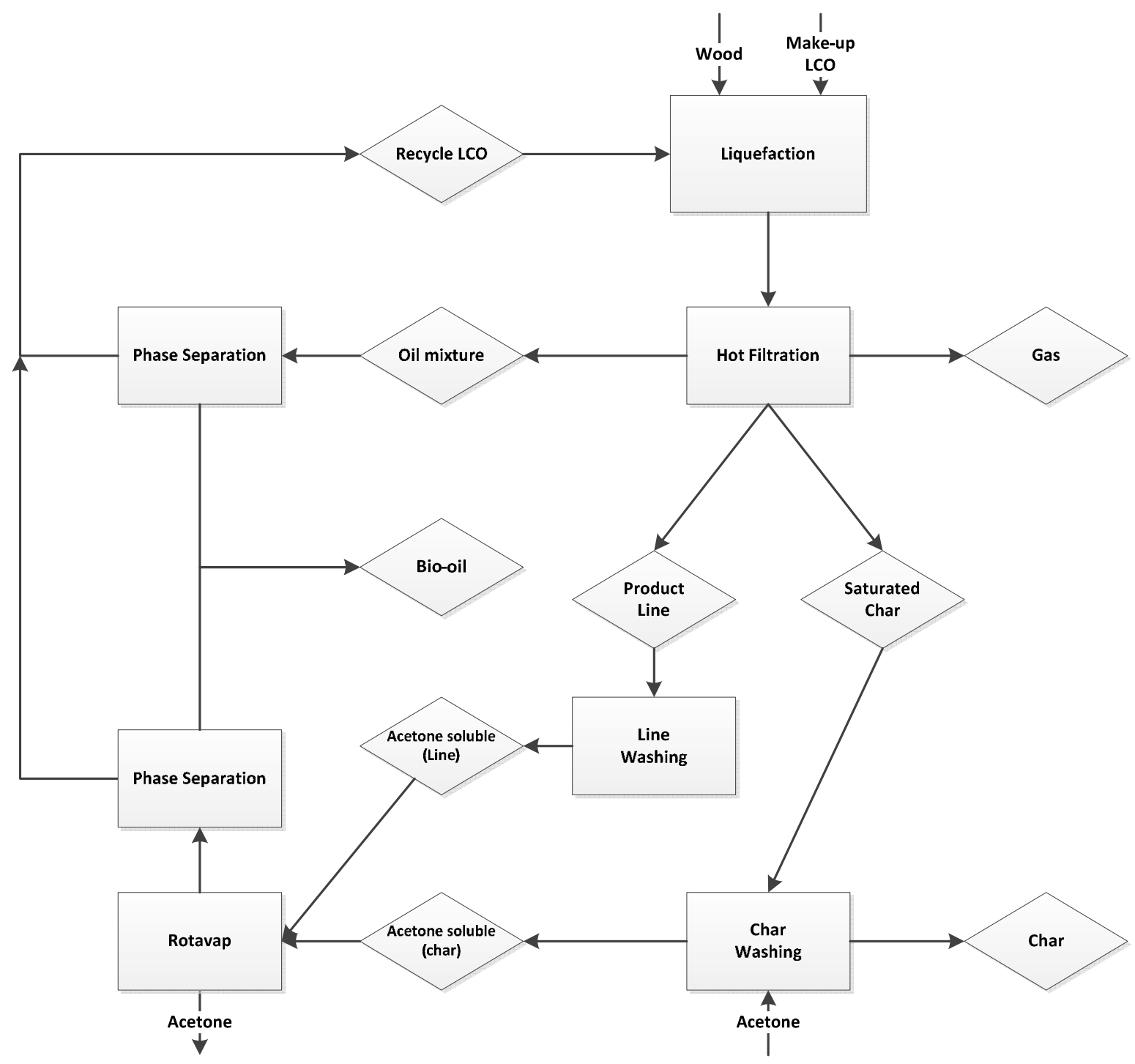

Figure S 2: Experimental procedure of refill experiments.

- Products yields in refill experiments

The product yields ( $\mathrm{w} \%$ ) of the refill experiments carried out in the $45 \mathrm{~mL}$ autoclave are shown in Figure S 3, while product yields $(\mathrm{C} \%)$ of the refill experiments carried out in the $560 \mathrm{~mL}$ autoclave are shown in Figure S 4. 


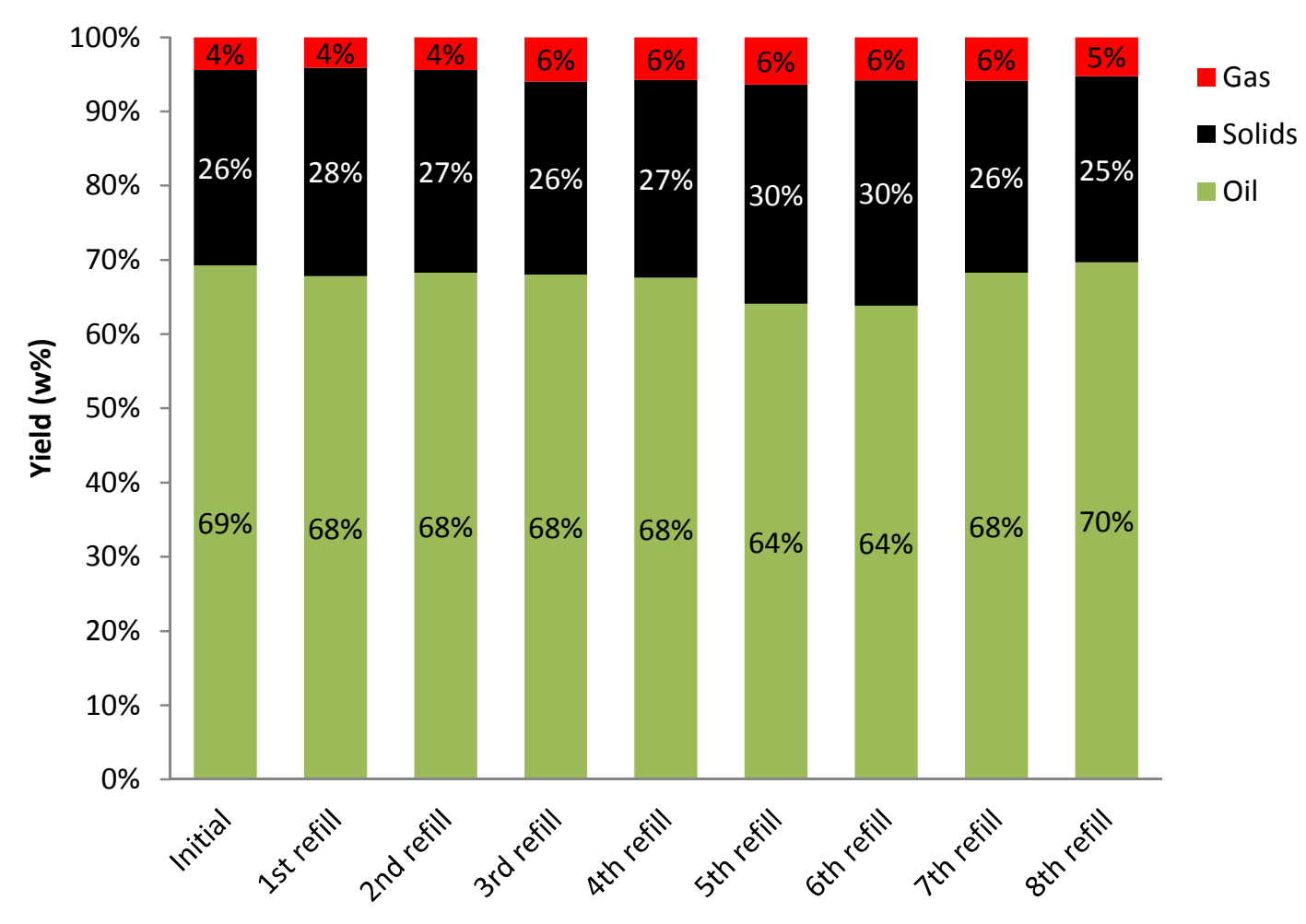

Figure S 3: Products yields obtained in the refill runs using separated LCO-rich phase in the 45 $\mathrm{mL}$ autoclave, $\tau=15 \mathrm{~min}$, Feed (w.\%); Solvent:Wood $=80: 20, \mathrm{~T}=320^{\circ} \mathrm{C}$.

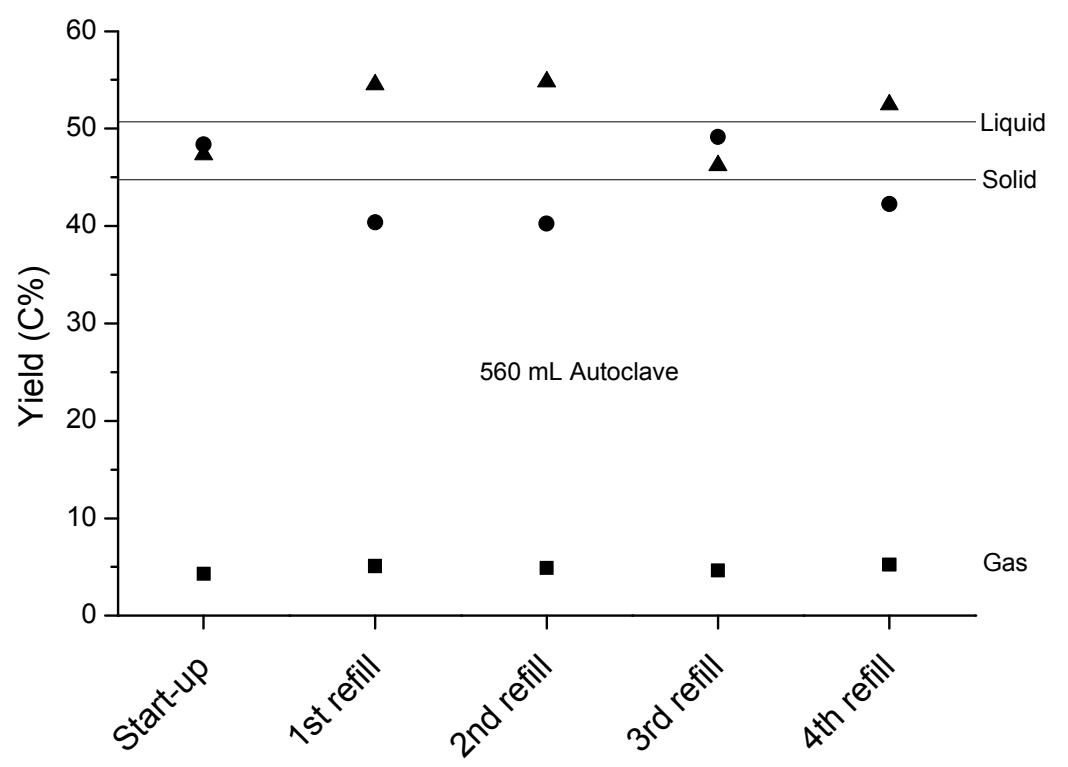

Figure S 4: Product yields obtained in the refill runs using the separated LCO-rich phase in 560 $\mathrm{mL}$ autoclave, $\tau \sim 100 \mathrm{~min}$. Feed (w\%); Solvent:Wood $=80: 20, \mathrm{~T} \sim 320^{\circ} \mathrm{C}$. 


\section{Break-down of the energy present in the wood (based on HHV):}

Energy in the char $(\%)=($ mass of char $\mathrm{x} \mathrm{HHV}$ of char $) /($ mass of wood $\mathrm{x}$ HHV of wood $) \times 100$

$$
=35 \%
$$

Energy in the gas $(\%)=($ mass of gas $\mathrm{x} \mathrm{HHV}$ of gas $) /($ mass of wood $\mathrm{xHHV}$ of wood $) \times 100$

$$
=1 \%
$$

Heat of reaction was assumed same as found in the earlier work with $\mathrm{VGO}^{2}$, which was $2.5 \%$ (exothermic) of HHV of wood.

Energy in the bio-crude $=100-(35+1+2.5)=61.5 \%$

\section{- Product characterization}

Apparent molecular weight distribution of the LCO-rich phase and the Bio-crude-rich phase obtained in the refill experiments are shown in Figure S 5. It is likely that the peak at around 60 $\mathrm{Da}$ in the GPC of the Bio-crude-rich phase is due to presence of LCO while a slight growing of heavy tail $\left(\mathrm{M}_{\mathrm{W}, \mathrm{GPC}}>150 \mathrm{Da}\right)$ in the GPC of LCO-rich phase would likely due to presence of the bio-crude. 

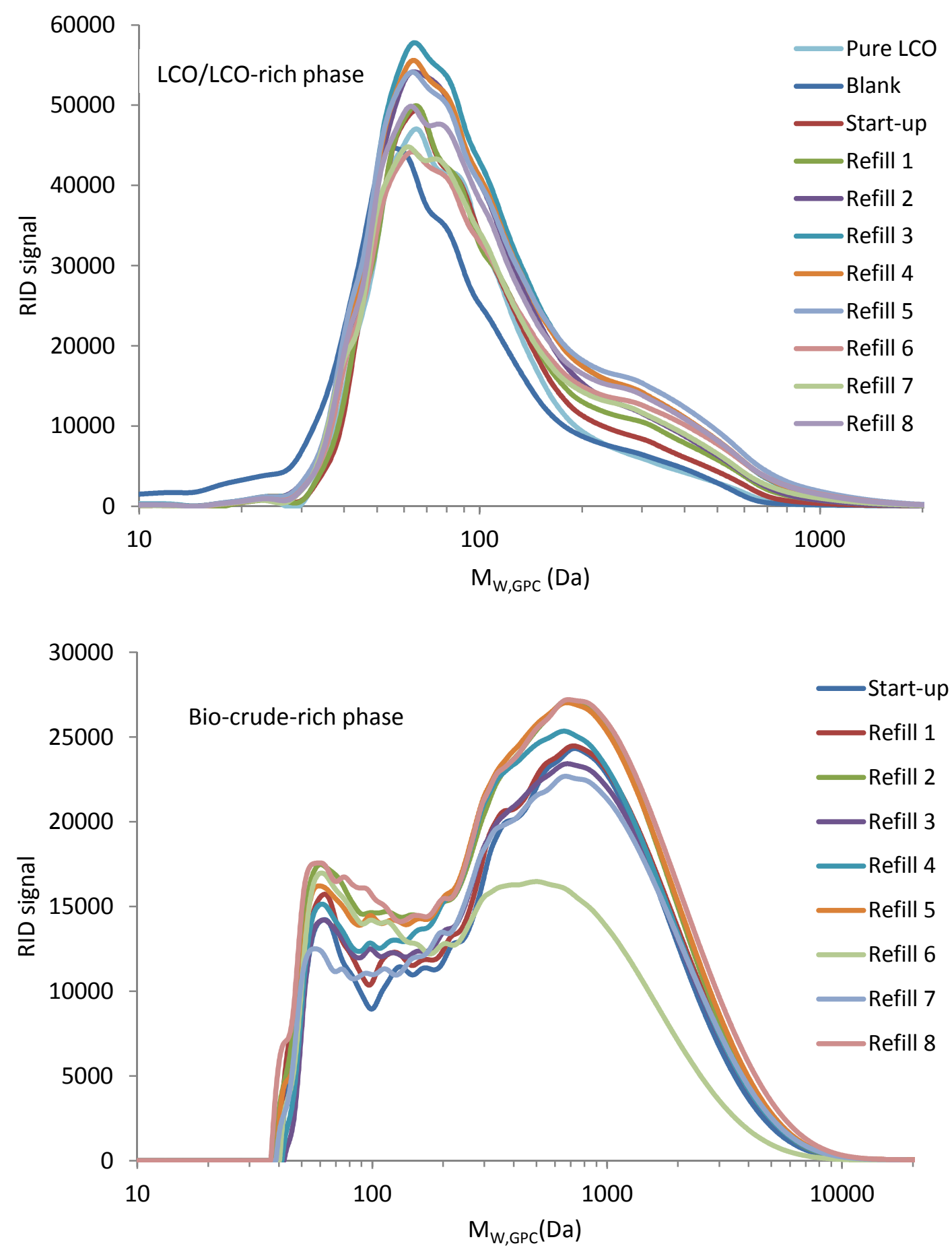

Figure S 5: Apparent molecular weight distribution of LCO-rich phase (top) and Bio-crude-rich phase (bottom) obtained in the refill experiments. Autoclave: $45 \mathrm{~mL}, \tau=15 \mathrm{~min}$, Feed (w\%); Solvent:Wood $=80: 20, \mathrm{~T}=320^{\circ} \mathrm{C}$. Blank run is without wood. 
The viscosity of the bio-crude-rich phase was measured at different temperatures and at different spindle rotation speeds, as depicted in Figure S 6 . The viscosity appeared to be fairly high, and to decrease with increasing temperature and, to a lesser extent, with increasing the rotation speed. This indicates that the produced bio-crude-rich phase behaved as a nonNewtonian fluid, i.e. the viscosity depends on the shear rate. The viscosity could not be measured at room temperature as it fell outside measurable range of the viscosity meter.

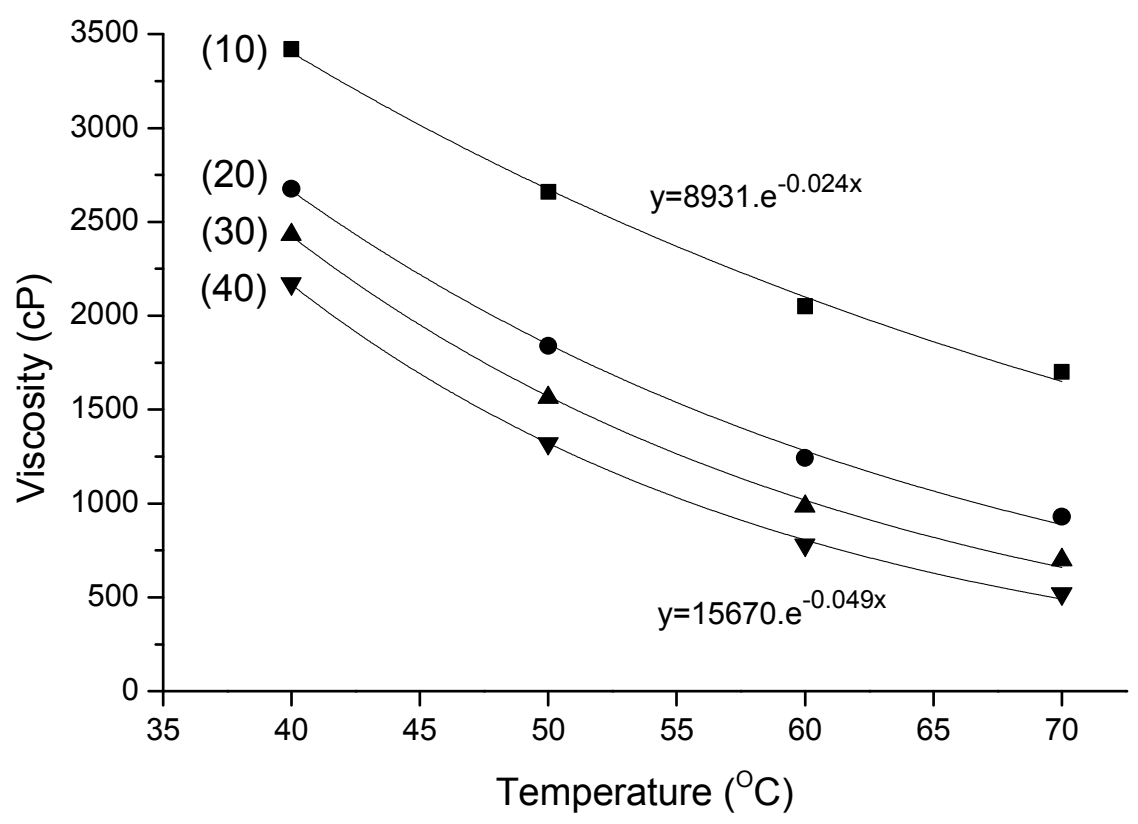

Figure S 6: Viscosity of the bio-crude-rich phase (from the $4^{\text {th }}$ refill in the $560 \mathrm{~mL}$ autoclave) at various temperatures and RPM (rotation per minute of spindle) rates (shown between the brackets).

The TAN of the bio-crude-rich phase and the LCO-rich phase obtained during the refill runs in the $560 \mathrm{~mL}$ autoclave are shown in Figure $\mathrm{S}$ 7. Accordingly, the acidity of the bio-crude-rich phase did not change significantly with the refill runs and remained around 50-60 mg/g. The marginal differences may be attributed to measurement errors. The TAN of the LCO-rich phase in all the refill runs was very low at $<10 \mathrm{mg} / \mathrm{g}$. A slight increase in the TAN during the $1^{\text {st }}$ refill 
and a constant value afterwards were possibly due to initial contamination of the LCO-rich phase with the bio-crude and its subsequent saturation.

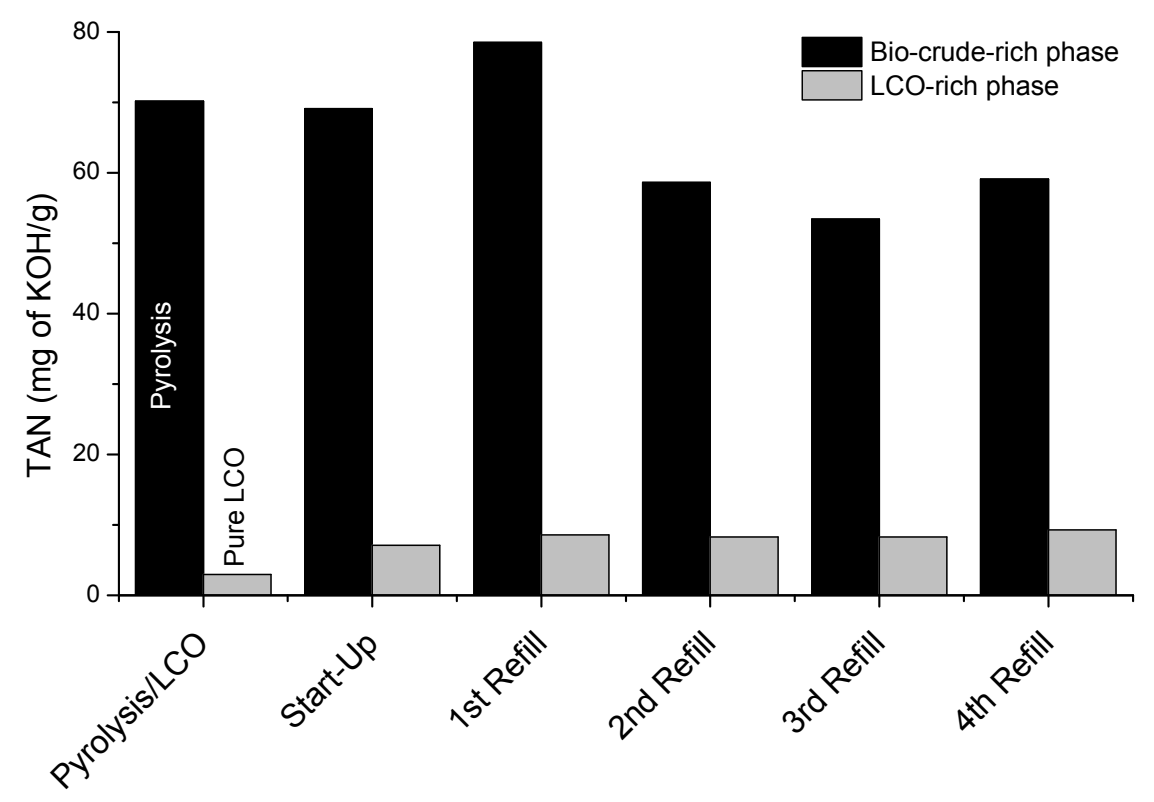

Figure S 7: TAN of pyrolysis oil ${ }^{3}$, pure LCO and the two phases (bio-crude-rich phase and LCOrich phase) obtained in the refill runs in the $560 \mathrm{~mL}$ reactor.

A micro carbon residue test (MCRT) was conducted to measure the coking tendency of the biocrude-rich phase, and results of the tests are shown in Figure S 8. The MCRT value of different bio-crude-rich phases obtained during the refill runs in the $560 \mathrm{~mL}$ autoclave varied between 25 and $33 \mathrm{w} \%$ 


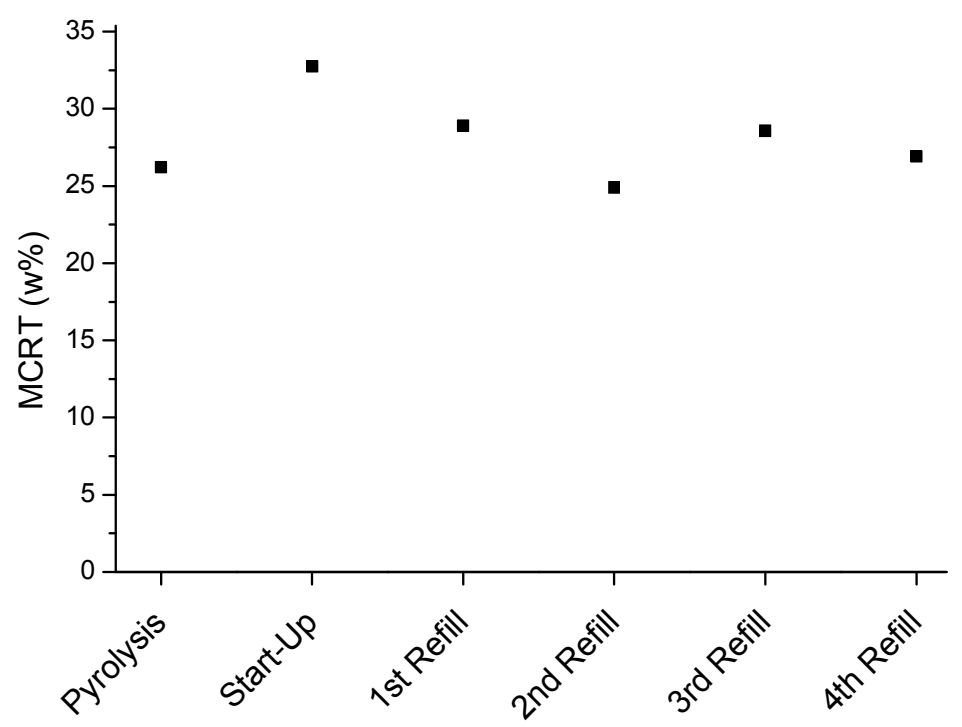

Figure S 8: MCRT of the pyrolysis oil ${ }^{4}$ and the bio-crude-rich phases obtained in the refill runs in the $560 \mathrm{~mL}$ reactor.

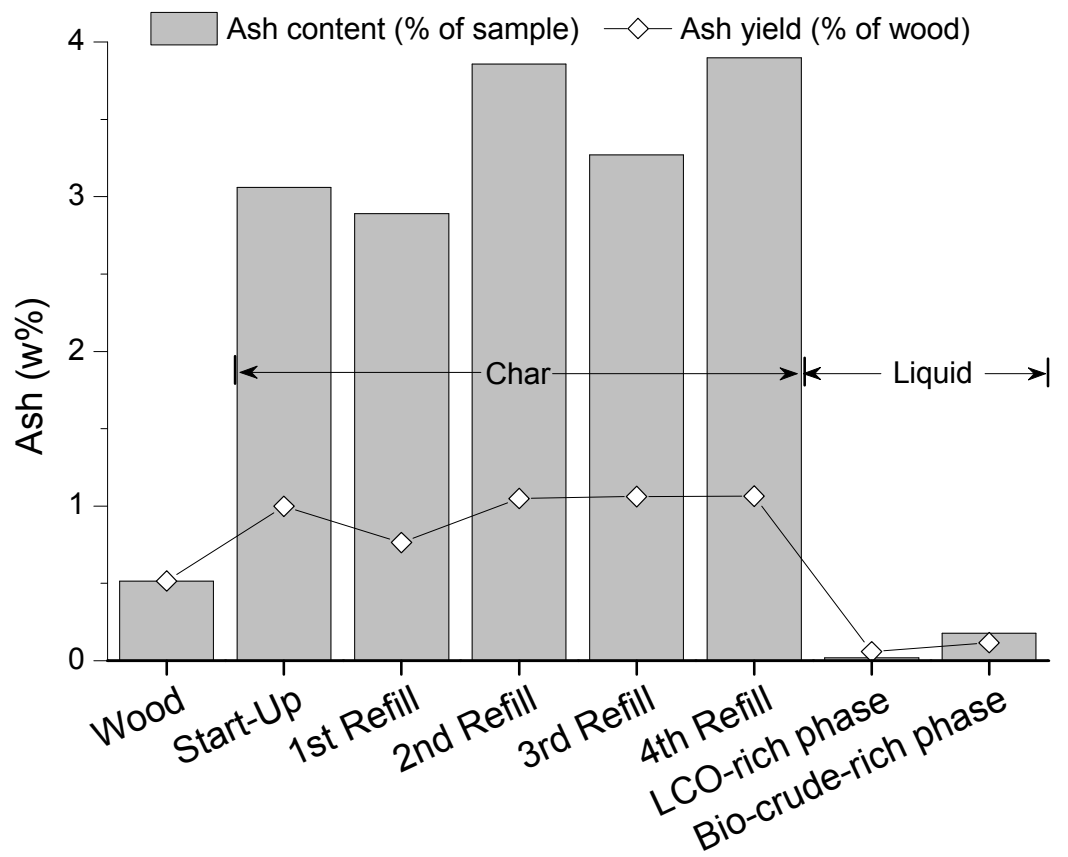

Figure S 9: Ash content (concentration) of chars obtained in the refill runs, LCO-rich phase and bio-crude-rich phase obtained in the $4^{\text {th }}$ refill run. The ash yield, as a percentage of the wood intake, is shown as a continuous line. The products are from the refill runs in the $560 \mathrm{~mL}$ reactor. 
Ash content of chars obtained in the refill runs, LCO-rich phase and bio-crude-rich phase obtained in the $4^{\text {th }}$ refill run (in $560 \mathrm{~mL}$ ) is shown in Figure S 9. Surprisingly, the ash content in the char is $\sim 6-8$ times the ash content of $0.5 \mathrm{w} \%$ measured in the wood. This is about double the yield that could be expected upon assuming that the entire ash ends up in the char and upon realizing that the char was produced with about $25 \mathrm{w} \%$ yield. A more detailed analysis of the ash using XRF revealed the presence of foreign elements in the char (Table S2). While the ash of the wood consisted mostly of calcium (41\%), it was dominated by iron for the bio-crude-rich phase and char (37 and $24 \%$ respectively). The presence of Iron, Chromium and Nickel in the ash of the bio-crude-rich phase and char confirms corrosion of the reactor wall ( $\mathrm{Ni} \sim 42 \%, \mathrm{Fe} \sim 22 \%, \mathrm{Cr}$ $\sim 21 \%$, Mo $\sim 3 \%, \mathrm{Cu} \sim 2 \%$ ). Further mass balance of these minerals indicates that the total amounts of Sulfur, Iron, Silicon, Aluminum, Chromium and Nickel found in the products (Biocrude-rich phase + Char) exceed the amounts that found in the feed wood. This suggests that these elements must partly come from the experimental unit.

Acid digestion was also applied to determine the ash content in the char and confirmed the results obtained with the earlier method. Hence it is not reported here. 
Table S 2: Minerals concentration in the ashes of the wood, bio-crude-rich phase and char, and their distributions in the two products namely bio-crude-rich phase and char, and Total base number (TBN) of the wood, bio-crude-rich phase and char. Sample from the $4^{\text {th }}$ refill in the 560 $\mathrm{mL}$ autoclave.

\begin{tabular}{ccccccc}
\hline & \multicolumn{3}{c}{$\begin{array}{c}\text { Ash composition } \\
\text { (w\% of ash) }\end{array}$} & \multicolumn{4}{c}{$\begin{array}{c}\text { Minerals balance } \\
\text { (w\% of mineral in wood) }\end{array}$} \\
\cline { 2 - 7 } & Wood & $\begin{array}{c}\text { Bio-crude-rich } \\
\text { phase }\end{array}$ & Char & $\begin{array}{c}\text { Bio-crude- } \\
\text { rich phase }\end{array}$ & Char & sum \\
& \multicolumn{5}{c}{ w\% } \\
$\mathrm{Ca}$ & 41 & 9 & 14 & 4 & 74 & 78 \\
$\mathrm{~K}$ & 10 & 11 & 3 & 21 & 68 & 89 \\
$\mathrm{~S}$ & 10 & 19 & 7 & 38 & 147 & $\mathbf{1 8 5}$ \\
$\mathrm{Mg}$ & 7 & 2 & 2 & 5 & 60 & 65 \\
$\mathrm{Mn}$ & 7 & 2 & 2 & 5 & 66 & 71 \\
$\mathrm{Fe}$ & 5 & 37 & 24 & 143 & 1020 & $\mathbf{1 1 6 3}$ \\
$\mathrm{P}$ & 1 & 0 & 0 & 1 & 85 & 86 \\
$\mathrm{Si}$ & 1 & 1 & 1 & 26 & 262 & $\mathbf{2 8 8}$ \\
$\mathrm{Ti}$ & 1 & 0 & 0 & 4 & 98 & $\mathbf{1 0 2}$ \\
$\mathrm{Al}$ & 1 & 0 & 1 & 16 & 266 & $\mathbf{2 8 2}$ \\
$\mathrm{Cr}$ & 0 & 2 & 5 & & & \\
$\mathrm{Ni}$ & 0 & 2 & 3 & & & \\
Undefined & 16 & 15 & 38 & 8 & 677 & 685 \\
\hline Sum & 100 & 100 & 100 & 271 & 2823 & n.a. \\
\hline Total ash (w\% in stream) & $\sim 0.5$ & $\sim 0.2$ & $\sim 3-4$ & n.a. & n.a. & n.a. \\
\hline TBN (mgKOH/g) & 9 & 1 & 23 & n.a. & n.a. & n.a. \\
\hline
\end{tabular}

Miscibility of Bio-crude-rich phase with VGO is shown in Figure S 10. 


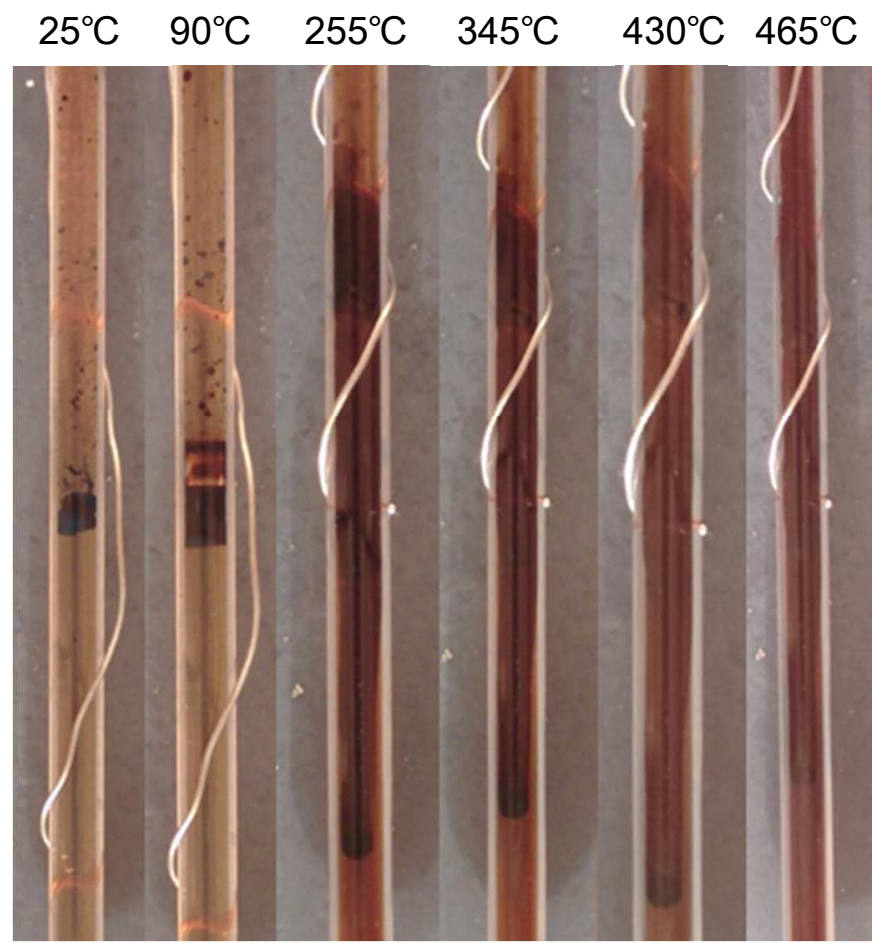

Figure S 10: Miscibility of the bio-crude-rich phase in VGO at different temperatures.

- Process modeling and simulation

Process flow diagram of the process concept with filtration of the solids is shown in Figure S 11. 


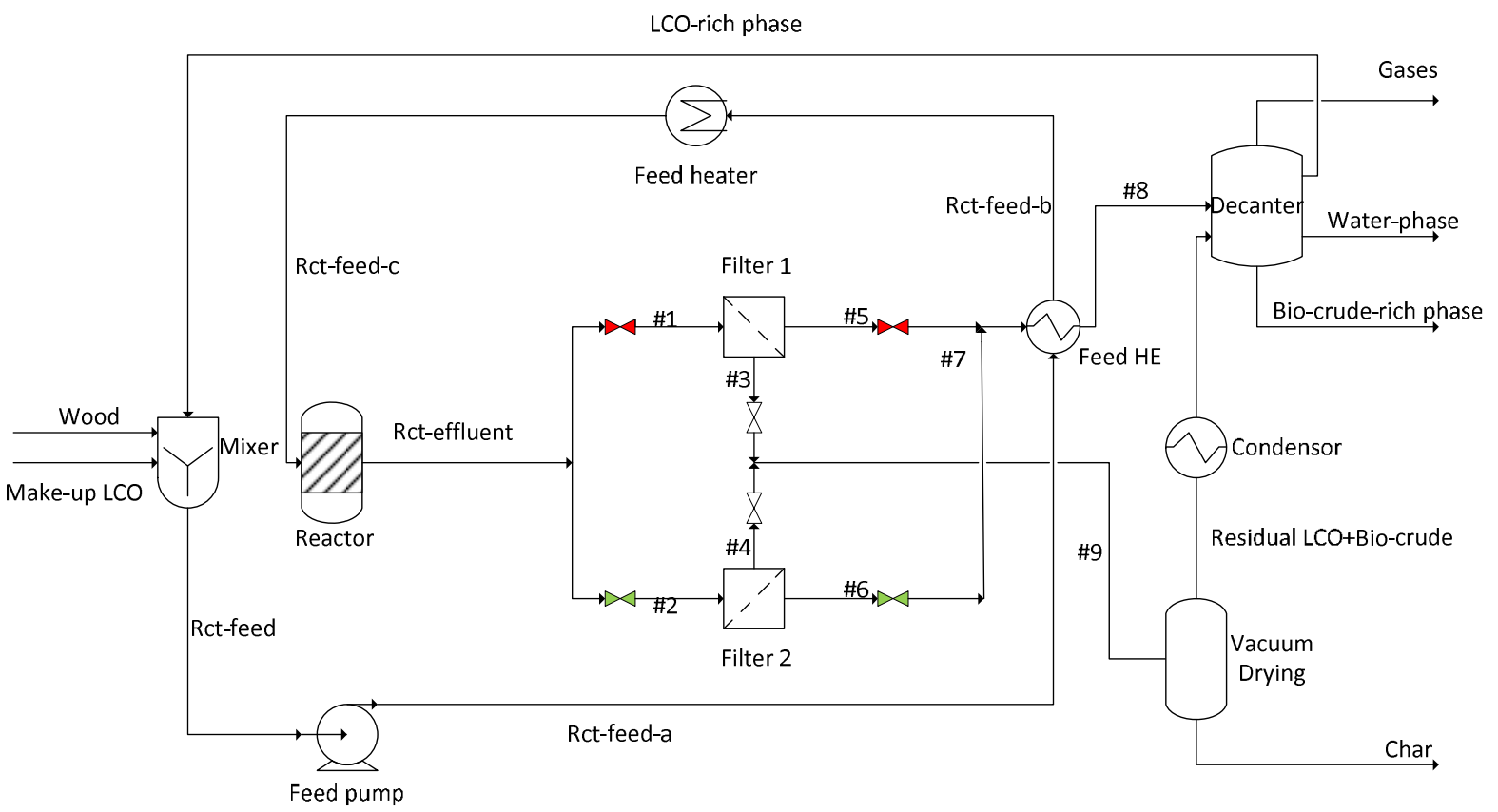

Figure S 11: Process flow diagram of liquefaction of wood in LCO with filtration of solids.

Ideal material balance was used for the process streams of the two process concepts that can be obtained from the material balance around the reactor (Table S3). Material balance around the liquefaction reactor is shown in Table S3. Energy duties of the process equipment are provided in Table S4.

Table S 3: Material balance around the liquefaction reactor. $\mathrm{T}: 320^{\circ} \mathrm{C}, \tau: 15 \mathrm{~min}$.

\begin{tabular}{ccccccc}
\hline & \multicolumn{6}{c}{ Liquefaction reactor (ton/h) } \\
\hline & Wood & LCO & Water & Bio-crude & Off gases & Char \\
Rct-Feed & 100 & 400 & 0 & 0 & 0 & 0 \\
Rct-effluent & 0 & 400 & 20 & 48 & 6 & 26 \\
\hline
\end{tabular}


Table S 4: Heat duty of heat transfer equipment of the process. Minimum approach temperature was set at $10^{\circ} \mathrm{C}$ in a heat exchanger.

\begin{tabular}{lcccc}
\hline & $\begin{array}{c}\text { Heat transfer } \\
(\mathrm{MW})\end{array}$ & $\begin{array}{c}\text { \% HHV of } \\
\text { wood }\end{array}$ & Remarks & $\begin{array}{r}\text { Temp. Change (Hot } \\
\text { side/Cold side) }{ }^{\circ} \mathrm{C}\end{array}$ \\
\hline Feed pump & $1.8^{*}$ & 0.34 & Electrical & \\
Feed HE & 86.8 & N/A & Heat exchanger & $(320-78) /(64-310)$ \\
Feed heater & 4.2 & 0.80 & Heating & $310-320$ \\
Vacuum & 9.1 & 1.7 & Heating & \\
Vac. drying & 7.2 & N/A & Cooling & \\
*Eergy consumption & & & &
\end{tabular}

\section{- Techno-economic assessment}

The economic feasibility of the process was assessed using the procedure described in the book "Conceptual Design of Chemical Processes" by James M. Douglas and can be summarized below.

\section{Assumptions}

$\begin{array}{ll}\text { Start-up } & =10 \% \text { of Fixed capital investment }(\mathrm{FCI}) \\ \text { Working capital } & =15 \% \text { of FCI } \\ \text { Offsite costs } & =45 \% \text { of Onsite costs } \\ \text { SARE } & =25 \% \text { of total Revenue } \\ \text { Maintenance } & =4 \% \text { of FCI } \\ \text { Supply } & =15 \% \text { of maintenance cost }\end{array}$


$\begin{array}{ll}\text { Supervision } & =20 \% \text { of labor cost } \\ \text { Lab } & =15 \% \text { of labor cost } \\ \text { Royalty } & =3 \% \text { of total production cost } \\ \text { Fixed charges } & =3 \% \text { of FCI } \\ \text { Depreciation } & =10 \% \text { of FCI } \\ \text { Owner's cost } & =5 \% \text { of direct costs } \\ \text { Contingency } & =\text { Calculated based on burning char } \\ \text { Utility costs } & =10 \% \text { of total production costs } \\ \text { Labor costs } & =60 \% \text { of Labor, supervision and maintenance costs } \\ \text { Plant OVHD } & \end{array}$

Onsite capital $=$ See duty-capex correlation (equation, S.1)

Direct cost $=$ onsite + offsite $=1.45$ onsite

Indirect cost $=$ Owner's cost + contingency $=0.25$ direct cost

Fixed capital $=$ direct $\cos t+$ indirect $\cos t=1.25$ direct $\cos t=1.81$ onsite

Total investment $=$ fixed capital + working capital + startup $=1.25$ fixed capital $=\mathbf{2 . 2 6}$ onsite

Total Production cost $=$ Manufacture cost + SARE

SARE $\sim 0.025$ (Revenue)

Manu. Cost $=$ Direct prod. Cost + Fixed charges + plant OVHD

Direct prod. cost $=$ Raw matl. + Utility + Maintenance + Op. Supply + labor + supervision + Laboratory + Royalty

Maintenance $=0.04$ fixed capital 
Supply $=0.15$ maintenance $=0.15 * 0.04$ fixed capital

Supervision $=0.2$ labor

$\mathrm{Lab}=0.15$ labor

Royalty $=0.03$ total prod. cost

Direct Prod. Cost $=$ Raw Matl. + Utility $+0.046(\mathrm{FCI})+1.35$ (labor) +0.03 (tot prod. cost)

Fixed charges $=$ Tax + insurance + rent + interest + Capital cost charges (due to investment $)$

Tax + insurance $=0.03$ fixed capital

Interest $=0$; i.e. $100 \%$ equity financed

Rent $=0$

Capital charges is derived with the annuity method employing a 10\% interest rate and a service life of 20 years as given by below equation.

Capital cost charges $=$ Capital Recovery Factor $\times$ Total investment

Capital Recovery Factor $=\mathrm{i}(1+\mathrm{i})^{\mathrm{n}} /\left((1+\mathrm{i})^{\mathrm{n}}-1\right)$; here $\mathrm{i}=$ interest rate, $\mathrm{n}=$ service life of the project

Fixed charges $=0.03$ Fixed cap. + Capital cost charges

Plant OVHD $=0.6($ Labor + supervision + maintenance $)$

$=0.72$ Labor +0.024 Fixed Cap.

Total Prod. Cost $=$ Direct prod.+ Fixed chg. + Plant OVHD + 0.025 Revenue

$=1.03$ (raw matl. + Utility $)+2.13$ labor +0.103 Fixed cap. +0.025 Revenue + Capital cost charges

In this study the onsite cost was calculated using the correlation suggested by Lange ${ }^{5}$ as given by equation S.1, which is corrected for the investment cost for the year 2014 by replacing the 
original factor of 2.9 with 4.7 to account for cost escalation from 1993 to 2014 . Rest of the calculations were done based on the procedures mentioned above.

Onsite cost $[M \$ 2014]=4.66 \times(\text { energy transfer }[M W])^{0.55}$

\section{References:}

(1) Westerhof, R.; Kuipers, N.; Kersten, S.; van Swaaij, W. Controlling the Water Content of Biomass Fast Pyrolysis Oil. Industrial \& Engineering Chemistry Research 2007, 46 (26), 92389247.

(2) Kumar, S.; Lange, J.-P.; Van Rossum, G.; Kersten, S. R. A. Liquefaction of Lignocellulose in Fluid Catalytic Cracker Feed: A Process Concept Study. ChemSusChem 2015, 8 (23), 4086-4094.

(3) Oasmaa, A.; Elliott, D.; Korhonen, J. Acidity of Biomass Fast Pyrolysis Bio-oils. Energy Fuels 2010, 24 (12), 6548-6554.

(4) de Miguel Mercader, F.; Groeneveld, M.; Kersten, S.; Geantet, C.; Toussaint, G.; Way, N.; Schaverien, C.; Hogendoorn, K. Hydrodeoxygenation of pyrolysis oil fractions: process understanding and quality assessment through co-processing in refinery units. Energy Environ. Sci. 2011, 4 (3), 985-997.

(5) Lange, J.-P. Fuels and Chemicals Manufacturing; Guidelines for Understanding and Minimizing the Production Costs. CATTECH 2001, 5 (2), 82-95. 